\title{
The stone circle
}

The Tao is a whole. - Fritjof Capra

Twas enjoying a beautiful sunset at my home in the Himalayas when my local caretaker broke the silence. He wanted me to take a look at his ailing father.

I fetched my stethoscope and we set off down the narrow slopes to the old man's hut. As we drew near, I became aware of the stench of disease pervading the fresh mountain air. My care\& taker's father had been losing weight steadily, coughing up blood-tinged sputum. His body was warm to the touch. His lungs sounded coarse. He was probably suffering from tuberculosis, which was not uncommon in the region. He needed urgent treatment, but the nearest hospital was 100 kilometres away. His family gathered round. They wanted to know the cost of hospital care. I estimated it to be a few thousand rupees, less than a hundred American dollars. The old man refused to go.

\section{Deaf patient}

You can't make small talk with a pen.

A physician who talks too much,

a twentysomething patient with slender hands

and a diagnostic clipboard.

In an overflowing morning

we alternate scratching through the history.

Laborious, luxurious.

In the wait while she writes

the quiet is lovely and full:

the roll of the wheels on my stool,

air blowing through the ducts,

the rush of wet tires on Bayswater.

Tangible as my scribbled

'Pain? Fever? Nausea?'

The pelvic is pure procedure,

a silent demonstration on a model

that blinks, breathes.

I mute the clang of the speculum,

the rustle of packaged swabs.

No words, no audience, and I am no disturber of the peace.

Slanting up the margins

the writing, visit, calm, stretch on,

for side effects look sinister, omissions are obvious in print.

When pens are down, heads up, she signs thank-you;

with black hair, dark eyes, white teeth

she is bright and magnified.

\section{Martina Scholtens}

Family Physician

Vancouver, BC
His granddaughter's wedding was only a few weeks away, and the family needed all the money they had saved to pay for it.

We finally respected his decision. But he insisted on paying me for my visit. He offered me a black stone shaped in the form of a deity, which he had recovered from a climb in the mountains several years before. It had brought him good luck. He hoped it would aid me in my efforts to be a good doctor. Reluctantly, I took the stone and put it in my pocket. His sunken eyes appeared deeper than the surrounding valleys as I left his hut. The sun that had hidden behind these slopes appeared to be only a shadow of the true sun.

A few weeks later I was on my regular shift in the emergency room in a small community hospital in upstate New York. One of my regular patients was wheeled into the emergency room for the third time that month. He had been found lying drunk on the road by the paramedics. He told them that he had been just lying there after a few drinks. We went through our routine of long and fruitless investigations: CT scans, blood tests and urine screens. As expected, they turned out to be normal, aside from the elevated blood alcohol level. We sent him home, urging him not to drink again. In the back of my mind a thought niggled: How much had it cost to do all those tests?

Several months later my patient came to the emergency department again. Not having seen him for some time, I was a bit apprehensive about his condition, but he told me that after the last episode he had decided to stop drinking. He thanked me for my efforts and explained that he had come to return the stone that had fallen out of my pocket during his last visit.

I had completely forgotten about the stone and hadn't noticed it was missing. I was ashamed to realize that I had also forgotten all about the old man who gave it to me. That day I called home, only to find out that he had died the day before his granddaughter's wedding and that as a consequence the family had postponed the wedding for a year.

On the surface it seemed that my visit to the old man's hut and his decision to forgo treatment had been fruitless. But somehow I felt that the old man's death had meaning. Although I had failed to help him, his resilient spirit had inspired me. Perhaps his example had strengthened me as a doctor. Did his stone fall into the hands of a patient half a world a way merely by chance? I do not know. I do not believe in miracles, but I know he somehow played a role in the life of my patient in America. Hidden from the surface was the truth that my patients from miles across the globe and I held a common thread of life and hope that bound us together.

\section{Sonal Singh}

Department of Medicine

Unity Health System

Rochester, NY 